\title{
A talaj elektromos vezetőképessége és a termőhelyi zónák talajtulajdonságai közötti összefüggések
}

\author{
${ }^{1 *}$ Kocsis Mihály, ${ }^{2}$ MenYHÁRT László, ${ }^{3}$ BenŐ András és ${ }^{4}$ Hermann TAMÁs \\ ${ }^{1}$ Magyar Agrár- és Élettudományi Egyetem, Környezettudományi Intézet, Környezeti \\ Fenntarthatóság Tanszék, Georgikon Campus, Keszthely; ${ }^{2}$ Magyar Agrár- és \\ Élettudományi Egyetem, Keszthely; ${ }^{3}$ Agrártudományi Kutatóközpont, Talajtani Intézet, \\ Talajtérképezési és Környezetinformatikai Osztály, Budapest; ${ }^{4}$ Felsőbbfokú \\ Tanulmányok Intézete, Köszeg \\ (Beérkezett: 2020.10.09.; Elfogadva: 2021.04.20.)
}

\section{Bevezetés}

A térinformatika tudományterületének fejlődése, a geostatisztikai módszerek széles tárháza, valamint a nagy térbeli felbontású távérzékelt adatok napjainkra lehetővé tették a földmüvelési egységeken belüli, talajváltozati folt szintű különbségek könnyebb értelmezhetőségét és elemzését. A térinformatika által szintetizált eredmények révén a precíziós növénytermesztés termőhelyspecifikusan kezeli a táblán vagy parcellán belül elkülöníthetö talajváltozatokat. Azok évjárathatásonkénti termőképességének tér- és időbeli variabilitását meg is jeleníti (MOORE et al. 1993).

Elsősorban Észak-Amerikában és Nyugat-Európában kibontakozó precíziós gazdálkodási technológia az utóbbi 20 évben Magyarországon gyorsuló ütemben gyürüzik be és terjed (TAMÁs 2001). GYŐRFFY (2000), majd MESTERHÁZI (2011) véleménye szerint a precíziós növénytermesztés feladata, hogy az eltérő sajátosságokkal rendelkező talajváltozati foltokon a talaj heterogenitásából eredően a növénykultúra termőhely igénye szempontjából a különböző víz- és tápanyagellátottságú talajfoltokat határolják körül. Hazánk termőterületeit talajtani és tápanyag-gazdálkodási viszonyaik alapján igen nagyfokú változatosság jellemzi. A precíziós szántóföldi növénytermesztést ezért elsősorban a termőhelyek változatossága és védelme is indokolja (AMBRUS 2016). A precíziós technológia létjogosultságát MARTON (2006) a táblákon belüli különbözö tápanyag-ellátottsági szintek kezelésében látta. A precíziós szántóföldi növénytermesztés egyik alapinformációját a hozamtérképek szolgáltatják, amelyek a táblán vagy parcellán belüli - a termőhelyi zónákhoz köthető - hozamkülönbségeket mutatják meg. A hozamkülönbségek (hozamingadozások) alapján képet kaphatunk a talajok termékenységén keresztül a talajviszonyokról, a tápanyag-gazdálkodásukról és az alkalmazott agrotechnika színvonaláról (SZÉKELY, 2000).

HERMANN és munkatársai $(2014 \mathrm{a} ; 2014 \mathrm{~b})$ az Agrokémiai Információs és Irányítási Rendszer (AIIR) adatbázis táblaszintü adatsorain arra végeztek vizsgálatokat, hogy a csernozjom és a barna erdőtalajú termőhelyeken, különbözö (kedvezö és kedvezötlen) évjáratokban, a talaj foszfor- és humusz ellátottsága milyen

*Levelezö szerzö: Kocsis MiHÁly, Magyar Agrár- és Élettudományi Egyetem, Környezettudományi Intézet, Környezeti Fenntarthatóság Tanszék, Georgikon Campus; H-8360 Keszthely, Deák Ferenc utca 16.

E-mail: kocsis.mihaly@uni-mate.hu 
hatással volt a kukorica terméshozamok alakulására. Arra a következtetésre jutottak, hogy a kedvező természetes növényi vízellátású évjáratban a csernozjom talajon a magasabb foszfor-ellátottságnak már nem volt termésnövelő hatása. Kedvezötlen évjáratban a talaj növekvő foszfor-ellátottsága mindkét termőhelyen terméscsökkenést okozott. Eredményeik azt mutatták továbbá, hogy kedvező évjáratban a csernozjomokon és a barna erdőtalajokon a közepes humusztartalmú talajokon is magas kukoricahozamok várhatók. Csernozjom talajokon kedvező évjáratban a közepes ellátottságig a humusztartalom mintegy 15\%-os termésnövelő hatását figyelték meg. A barna erdőtalajokon a kedvező évjáratban közepes humuszellátottságig szintén hozamnövekedést tapasztaltak.

Az intenzív mezőgazdasági tevékenység, mint emberi beavatkozás, a térben igen változatos talajokra is jelentős hatást gyakorol (YOST et al. 1982), mellyel elsősorban a termőképességük változik meg. VÁRALLYAY (2012) szerint a talajok termékenységét befolyásoló elsődleges talajtulajdonságok (textúra, humusztartalom, kémhatás stb.) és azok területi és talajon belüli elhelyezése, azaz lokális felismerése az egyik legnagyobb kihívás. A talajfoltok nagymértékủ térbeli heterogenitásának legfontosabb okozója az elsődleges talajtulajdonságok igen nagy változékonysága (MELCHIORI et al. 2002), amelyet a valóságban nem könnyủ leképezni és számszerüsíteni. A talajtulajdonságok nemcsak elsődlegesek (kvantitatív vagy kvalitatív), hanem másodlagosak (származtatott jellemzők) is lehetnek. A talajok funkcióikra és folyamataikra, vagy szolgáltatásaikra vonatkozó ismereteket is hordozhatnak (PÁszTOR et al. 2014). Korábban a térinformatikai és a szenzoros módszerek (pl. légi lézerszkennelés, hiperspektrális távérzékelés és talajszkennelés) megjelenése előtt, a térképező talajtani tudására és tapasztalatára hagyatkozva, a rendelkezésre álló talajinformációk és szintvonalas térképek alapján kézzel határolta le a talajváltozati foltokat (MACHANDA et al. 2002). A talajtulajdonságok elhelyezkedését, kiterjedését, valamint azok térbeli változékonyságát származtatott adatokból lehet becsülni, alapvetően a környezeti tényezők talajra gyakorolt hatása alapján (SCULL et al. 2003). Közvetett talajinformációk nyerhetők a különféle légiés ürfelvételezések alapján készített domborzati modellekből és az azokból levezetett geomorfológiai jellemzőkből (pl. lejtőszög, lejtőgörbület, kitettség, völgymélység stb.) (MiLLER \& SCHAETzL, 2014). A távérzékelésből származtatott adatok a növénytermesztés növénymonitoringjához és termésbecsléséhez (ALLEN 1977), valamint a termést gátló tényezőkhöz, pl. a talajerózió mértékének megállapításához is felhasználhatók. A müholdfelvételekből származtatott adatok alapján kiszámítható a termőterületek zöldtömeg-indexe, ami tájékoztat a tenyészidőszakban az adott növénykultúrák állapotáról. A normalizált differenciált vegetációs index (NDVI) évjáratonként és növényspecifikusan jelzi a talajok termőképességét. Értékeinek kategorizálásával jellemezhetők és lehatárolhatók a tulajdonságokban is eltérő talajfoltok, amelyek felhasználhatók a precíziós mủvelési zónák kialakításához. Az NDVI mutatószámot, és annak változatát, a továbbfejlesztett vegetációs indexet (EVI), valamint a normalizált differenciált vízindexet (NDWI) potenciális termésbecslésekre (YE \& SAKAI 2011) és a felszín közeli talajrétegek víztartalmának becslésére is alkalmazzák (GULÁCSI \& KOVÁCS 2015). 
A felszín közeli $(0-90 \mathrm{~cm})$ talajrétegek vizsgálatára egyre gyakrabban és elterjedtebben használják az elektromos vezetőképességen (EC) és a talajellenállás mérésen alapuló talajszkenner készülékeket (PERALTA et al. 2013). A talajvezetőképesség a talajoldatban oldott, töltéssel rendelkezö ionok, illetve részecskék számától és anyagi minőségétől függ (RHOADES et al. 1989; CORWIN \& LESCH 2003). A mért elektromos vezetőképesség értékét meghatározza a talaj víztartalma, textúrája, agyagásvány összetétele, humusz- és mésztartalma, kémhatása és vízben oldható összes sótartalma (KACHANOSKI et al. 1988; JOHNSON et al. 2001; KAFFKA et al. 2005). Megállapították (CORWIN \& LESCH 2003; SUDDUTH et al. 2003), hogy a mért EC értékek és az egyes talajparaméterek között gyenge statisztikai összefüggés mutatható ki. Viszont MORAL és munkatársai (2010) szerint a talajtulajdonságok változása nyomon követhető az EC méréseken keresztül, így a talajok térbeli heterogenitásáról - a talajváltozati foltok elhelyezkedéséről - kaphatunk képet, amelyek segítségével egyszerüen és gyorsan meghatározhatók az eltérő termékenységű termőhelyi zónák.

A precíziós növénytermesztés bevezethetőségének, illetve elindításának alapfeltétele, hogy a mezőgazdasági táblákon vagy parcellákon belül meg lehessen különböztetni a változati szintủ talajfoltokat, és azok kellő biztonságú lehatárolását. A talajtulajdonságok táblán belüli térbeli heterogenitásának lehatárolása adhat tehát alapot a mezőgazdasági müvelés agrotechnikai elemeinek táblán belüli differenciálására. Természetesen nem az összes agrotechnikai beavatkozásnak kell ezekhez a talajfoltokból eredeztethető zónákhoz kötődnie. Vannak olyan müveletek is (mint például egyes növényvédelmi beavatkozások), melyeket egyéb kritériumok alapján differenciálnak a táblán belül. Ettől függetlenül a precíziós gyakorlat azt mutatja, hogy a legtöbbet használt precíziós mezőgazdasági technikák közül a tápanyag-gazdálkodás és a vetés differenciálása legtöbbször a talajtulajdonságok heterogenitása alapján kialakított zónákra vonatkozik. Mindez a térbeli felbontás jelentős növekedésével lehetővé teszi, hogy az eddig egy egységként kezelt táblák helyett, a földmüvelés új alapjának a talajfoltokat tekintsük. Ez nem jelent mást, mint a terület egyes termőhelyi (müvelési) zónáinak elkülönítését. A művelésre kijelölt táblák talajtani szempontból sosem tekinthetők homogén földmüvelési egységnek, hanem térben változatos, különböző tulajdonságú talajváltozati foltokból összetevődőnek. A talajfoltoknak minden esetben más és más a víz- és tápanyagszolgáltató képességük a növények számára, így termékenységük is akár nagyon eltérő lehet.

A művelési zónák lehatárolása nagy odafigyelést igényel, ami eddig jobbára tradicionális terepi felvételezésen és talaj-mintavételezésen, majd a talajminták laboratóriumi vizsgálatán alapult. Ez nagyon költség-, idő- és munkaigényes feladat. A müvelési zónák lehatárolásának talajinformáció igénye, - remélhetőleg a közeljövőben - ha nem is helyettesíthető vagy kiváltható, de legalább kiegészíthető más, távérzékelésből származtatott (pl. NDVI), talajközeli és szenzorosan mért, pl. talaj-vezetőképesség (conductivity) és mágneses térerősség (magnetic susceptibity) adatokkal. Ezáltal a talajmüvelési zónák beazonosítása és elkülönítése leegyszerüsödhet, az eddigiekhez képest gyorsabbá és rutinszerüvé válhat. 
Kutatási célunk egy dombvidéki mintaterület tábláin megvizsgálni a mért talajellenállás értékek alapján lehatárolt termőhelyi zónák, illetve a talajtulajdonságaik közötti összefüggéseket. Statisztikai elemzésekkel kerestük a talajszkennerrel mért talaj-vezetőképesség és a termőhelyi zónák talajvizsgálati eredményei közötti kapcsolatokat. Arra voltunk kíváncsiak, hogy a mért EC értékek, illetve az azok alapján elkülönített termőhelyi zónák miként és hogyan jellemzik a táblák talajviszonyait. Milyen mértékü a talajszkennelés által mért értékek szerinti művelési zóna-lehatárolások megbízhatósága?

\section{Anyag és módszer}

A vizsgálatunkhoz kiválasztott 6 táblából álló 143,6 hektáros mintaterületen a zimányi Farkas Kft. gazdálkodik, 2012 óta folytat mintegy 650 hektáron integrált, vetésforgós precíziós szántóföldi növénytermesztést. A kiválasztott táblákon az utóbbi két évben (2018-ban és 2019-ben) őszi búzát, repcét, napraforgót és csemege borsót termesztett. A mintaterület táblái szétszórtan Somogy megyében, a Dunántúlidombság nagytájon belül, a Külsö-Somogy középtáj, Nyugat-Külsö-Somogy és DélKülsö-Somogy kistájak (DöVÉNYI et al. 2010) területén helyezkednek el. Jól mutatják a dombvidéki tájat jellemző domborzati- és talajtani sajátosságokat (1. ábra).

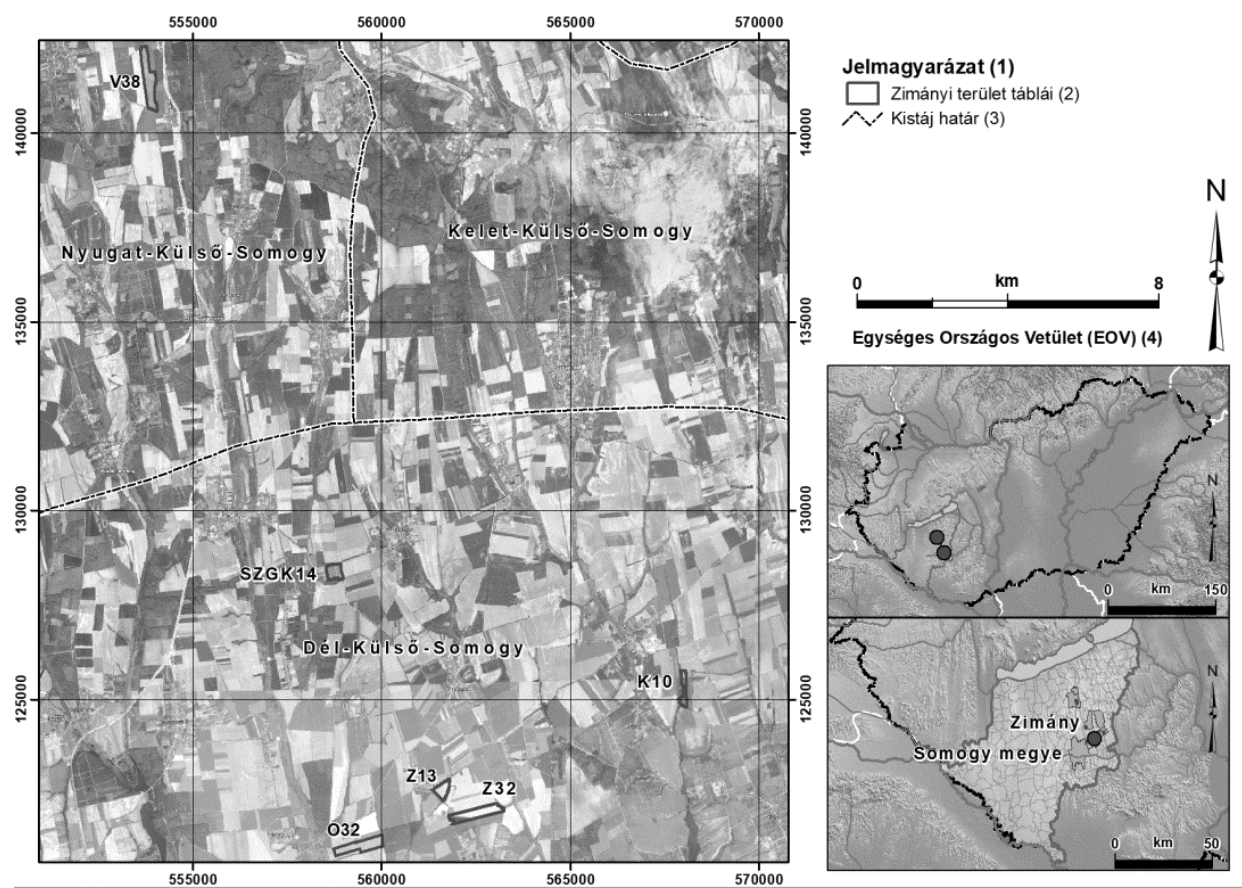

1. ábra

A zimányi mintaterület elhelyezkedése 
Az 1:200.000 méretarányú Magyarország MÉM NAK Genetikus talajtérképe (JENEY \& JASSÓ 1983; KoCSIS et al. 2015) szerint, illetve a jelenleg érvényben lévő hazai talajosztályozás (STEFANOVITS, 1963; SZABOLCS et al. 1966; JASSÓ et al. 1989) besorolása alapján a táblákra löszön kialakult, vályog fizikai féleségü és feltalajjal rendelkező típusos Ramann-féle barna erdőtalaj és karbonátos csernozjom barna erdőtalaj talajtípusok jellemzőek.

2019 tavaszán a földterületek talajai elektromos vezetöképességét $50 \mathrm{~cm}$-es és 100 cm-es mélységben mértük meg Geonics EM38-MK2 típusú talajszkennerrel. A méréseket a táblákon belül átlagosan 2 méteres pontsűrüséggel és a domborzati adottságoktól függően 15 méteres sortávolsággal végeztük el. Az $50 \mathrm{~cm}$-es mélységben mért vezetőképesség értékekeit $5 \mu \mathrm{S} \mathrm{cm}^{-1}$ szélességủ intervallumokba soroltuk, és az így kialakított kategóriák alapján határoltuk le a táblákon belül a termőhelyi (mủvelési) zónákat. A talajmintavételeket úgy terveztük, hogy a táblákon belül lehatárolt múvelési zónákat jól reprezentálják a mintavételi útvonalak átlagmintái

(2. ábra). A lehatárolt zónák területéről tehát minimum 15-20 részmintát gyüjtöttünk. A részminták ily módon a talajfolt (zóna) egészét reprezentálják. A kapott átlagminta információtartalma megbízható módon megfeleltethető a müvelési zónák jellemzésére (SZATMÁRI et al., 2015). Az átlagmintákat a talajmintavételi útvonalak mentén a táblák feltalajából $(0-30 \mathrm{~cm})$ vettük. A 6 tábláról vett 128 darab talajmintán a Magyar Szabványok (MSZ) alapján a teljeskörủ laboratóriumi talajvizsgálatokat végeztettük el (1. táblázat).

\section{1. táblázat}

A zimányi táblák talajmintáinak teljeskörü laboratóriumi talajvizsgálati jegyzéke

\begin{tabular}{|c|c|c|c|}
\hline $\begin{array}{c}\text { (1) } \\
\text { Vizsgált } \\
\text { talajparaméterek }\end{array}$ & $\begin{array}{c}\text { (2) } \\
\text { Mértékegység }\end{array}$ & $\begin{array}{c}\text { (3) } \\
\text { Meghatározás módszere }\end{array}$ & $\begin{array}{l}\text { (4) } \\
\text { Kimutatási határ / } \\
\text { Mérési tartomány }\end{array}$ \\
\hline Kötöttség & $\left(\mathrm{K}_{\mathrm{A}}\right)$ & MSZ-08-0205: 1978 & $25-60$ \\
\hline Humusztartalom & $\%$ & MSZ-08-0210: 1977 & $0,2 \%$ \\
\hline $\mathrm{pH}_{(\mathrm{KCl})}$ & - & MSZ-08-0206-02:1978 & $2-12$ \\
\hline $\mathrm{CaCO}_{3}$ & - & MSZ-20-135: 1999 & $0,25 \%$ \\
\hline $\mathrm{NO}_{3}-\mathrm{N}+\mathrm{NO}_{2}-\mathrm{N}$ & $\mathrm{mg} \mathrm{kg}^{-1}$ & MSZ-20-135: 1999 & $2,5 \mathrm{mg} \mathrm{kg}^{-1}$ \\
\hline $\mathrm{P}_{2} \mathrm{O}_{5}$ & $\mathrm{mg} \mathrm{kg}^{-1}$ & MSZ-20-135: 1999 & $25 \mathrm{mg} \mathrm{kg}^{-1}$ \\
\hline $\mathrm{K}_{2} \mathrm{O}$ & $\mathrm{mg} \mathrm{kg}^{-1}$ & MSZ-20-135: 1999 & $30 \mathrm{mg} \mathrm{kg}^{-1}$ \\
\hline $\begin{array}{l}\text { Vízben oldható } \\
\text { összes sótartalom }\end{array}$ & $\%$ & MSZ-08-0206-02:1978 & $0,02 \%$ \\
\hline $\mathrm{Mg}^{2+}$ & $\mathrm{mg} \mathrm{kg}^{-1}$ & MSZ-20-135: 1999 & $25 \mathrm{mg} \mathrm{kg}^{-1}$ \\
\hline $\mathrm{Na}^{+}$ & $\mathrm{mg} \mathrm{kg}^{-1}$ & MSZ-20-135: 1999 & $15 \mathrm{mg} \mathrm{kg}^{-1}$ \\
\hline $\mathrm{Zn}^{2+}$ & $\mathrm{mg} \mathrm{kg}^{-1}$ & MSZ-20-135: 1999 & $0,5 \mathrm{mg} \mathrm{kg}^{-1}$ \\
\hline $\mathrm{Cu}^{2+}$ & $\mathrm{mg} \mathrm{kg}^{-1}$ & MSZ-20-135: 1999 & $0,5 \mathrm{mg} \mathrm{kg}^{-1}$ \\
\hline $\mathrm{Mn}^{2+}$ & $\mathrm{mg} \mathrm{kg}-1$ & MSZ-20-135: 1999 & $10 \mathrm{mg} \mathrm{kg}^{-1}$ \\
\hline $\mathrm{SO}_{4}{ }^{2-}$ & $m g \mathrm{~kg}^{-1}$ & MSZ-20-135: 1999 & $2 \mathrm{mg} \mathrm{kg}^{-1}$ \\
\hline $\mathrm{Fe}^{2+}+\mathrm{Fe}^{3+}$ & $\mathrm{mg} \mathrm{kg}^{-1}$ & MSZ-20-135: 1999 & $10 \mathrm{mg} \mathrm{kg}^{-1}$ \\
\hline
\end{tabular}


A 2020 tavaszán elvégzett laboratóriumi vizsgálatok szerint a táblák müvelt talajrétege döntően vályog és agyagos vályog fizikai féleségü, domboldali és völgyfenéki helyzetétöl függően humusztartalma $0,61-2,31 \%$ közötti. A savanyú $(4,50-5,50 \mathrm{pH})$, a gyengén savanyú $(5,51-6,80 \mathrm{pH})$ talajféleségek mellett előfordulnak semleges $(6,81-7,20 \mathrm{pH})$ és gyengén lúgos $(7,21-8,50 \mathrm{pH})$ talajfoltok is. Ezek karbonát-tartalma igen széles határok között változik (0-14 \%). Jellemzően a szántókon karbonát-mentes, gyengén-, közepesen- és erősen karbonátos talajváltozatok találhatók (2. táblázat). A talaj vízoldható összes sótartalma 0,050\% alatti.

\section{2. táblázat}

A zimányi mintaterület főbb mért paramétereinek és a tengerszint feletti magasságoknak (tszfm (m)) alapstatisztikai eredményei

\begin{tabular}{|c|c|c|c|c|c|c|c|}
\hline $\begin{array}{c}\text { (1) } \\
\text { Táblakód }\end{array}$ & $\begin{array}{c}\text { (2) } \\
\text { Terület } \\
\text { (ha) }\end{array}$ & $\begin{array}{c}\text { (3) } \\
\text { Minta- } \\
\text { szám }\end{array}$ & $\begin{array}{c}\text { (4) } \\
\text { Mért } \\
\text { jellemzők }\end{array}$ & $\begin{array}{c}(5) \\
\text { Minimum }\end{array}$ & $\begin{array}{c}(6) \\
\text { Maximum }\end{array}$ & $\begin{array}{l}\text { (7) } \\
\text { Átlag }\end{array}$ & $\begin{array}{c}(8) \\
\text { Szórás }\end{array}$ \\
\hline \multirow{5}{*}{ K10 } & \multirow{5}{*}{11,23} & \multirow{5}{*}{32} & $\mathrm{~K}_{\mathrm{A}}$ & 42 & 54 & 48 & 3,65 \\
\hline & & & $\mathrm{H}(\%)$ & 0,84 & 2,25 & 1,79 & 0,29 \\
\hline & & & $\mathrm{pH}_{(\mathrm{KCl})}$ & 6,58 & 7,54 & 7,14 & 0,24 \\
\hline & & & $\mathrm{CaCO}_{3}(\%)$ & 1,0 & 14,0 & 3,76 & 2,92 \\
\hline & & & $\operatorname{tszfm}(\mathrm{m})^{*}$ & 133 & 147 & 143 & 3,45 \\
\hline \multirow{5}{*}{$\mathrm{O} 32$} & \multirow{5}{*}{31,75} & \multirow{5}{*}{15} & $\mathrm{~K}_{\mathrm{A}}$ & 32 & 48 & 41 & 5,71 \\
\hline & & & $\mathrm{H}(\%)$ & 1,32 & 1,80 & 1,59 & 0,15 \\
\hline & & & $\mathrm{pH}_{(\mathrm{KCl})}$ & 6,39 & 7,43 & 6,94 & 0,24 \\
\hline & & & $\mathrm{CaCO}_{3}(\%)$ & 0,6 & 10,2 & 3,0 & 3,56 \\
\hline & & & tszfm (m) & 137 & 151 & 143 & 5,44 \\
\hline \multirow{5}{*}{ SZGK14 } & \multirow{5}{*}{14,73} & \multirow{5}{*}{15} & $\mathrm{~K}_{\mathrm{A}}$ & 40 & 50 & 45 & 3,33 \\
\hline & & & $\mathrm{H}(\%)$ & 1,46 & 2,31 & 1,83 & 0,18 \\
\hline & & & $\mathrm{pH}_{(\mathrm{KCl})}$ & 6,30 & 7,43 & 6,93 & 0,39 \\
\hline & & & $\mathrm{CaCO}_{3}(\%)$ & 0,8 & 12,9 & 4,3 & 4,56 \\
\hline & & & $\operatorname{tszfm}(\mathrm{m})$ & 174 & 186 & 181 & 3,25 \\
\hline \multirow{5}{*}{ V38 } & \multirow{5}{*}{39,20} & \multirow{5}{*}{39} & $\mathrm{~K}_{\mathrm{A}}$ & 34 & 42 & 38 & 2,16 \\
\hline & & & $\mathrm{H}(\%)$ & 1,02 & 1,61 & 1,21 & 0,13 \\
\hline & & & $\mathrm{pH}_{(\mathrm{KCl})}$ & 6,38 & 7,61 & 7,23 & 0,39 \\
\hline & & & $\mathrm{CaCO}_{3}(\%)$ & 0,6 & 13,8 & 2,98 & 3,63 \\
\hline & & & tszfm $(\mathrm{m})$ & 173 & 210 & 187 & 6,82 \\
\hline \multirow{5}{*}{ Z13 } & \multirow{5}{*}{13,39} & \multirow{5}{*}{13} & $\overline{\mathrm{K}_{\mathrm{A}}}$ & 42 & 47 & 45 & 1,75 \\
\hline & & & $\mathrm{H}(\%)$ & 0,61 & 2,02 & 1,54 & 0,55 \\
\hline & & & $\mathrm{pH}_{(\mathrm{KCl})}$ & 6,04 & 7,40 & 7,05 & 0,45 \\
\hline & & & $\mathrm{CaCO}_{3}(\%)$ & 0,7 & 8,6 & 3,2 & 2,61 \\
\hline & & & tszfm (m) & 150 & 165 & 159 & 5,19 \\
\hline \multirow{5}{*}{$\mathrm{Z} 32$} & \multirow{5}{*}{33,31} & \multirow{5}{*}{14} & $\overline{\mathrm{K}_{\mathrm{A}}}$ & 42 & 50 & 45 & 2,76 \\
\hline & & & $\mathrm{H}(\%)$ & 1,58 & 2,13 & 1,72 & 0,14 \\
\hline & & & $\mathrm{pH}_{(\mathrm{KCl})}$ & 6,41 & 7,27 & 6,98 & 0,29 \\
\hline & & & $\mathrm{CaCO}_{3}(\%)$ & 0,7 & 7,5 & 3,5 & 2,46 \\
\hline & & & tszfm (m) & 147 & 165 & 159 & 5,77 \\
\hline
\end{tabular}

Megjegyzés: *tengerszint feletti magasság (m). 


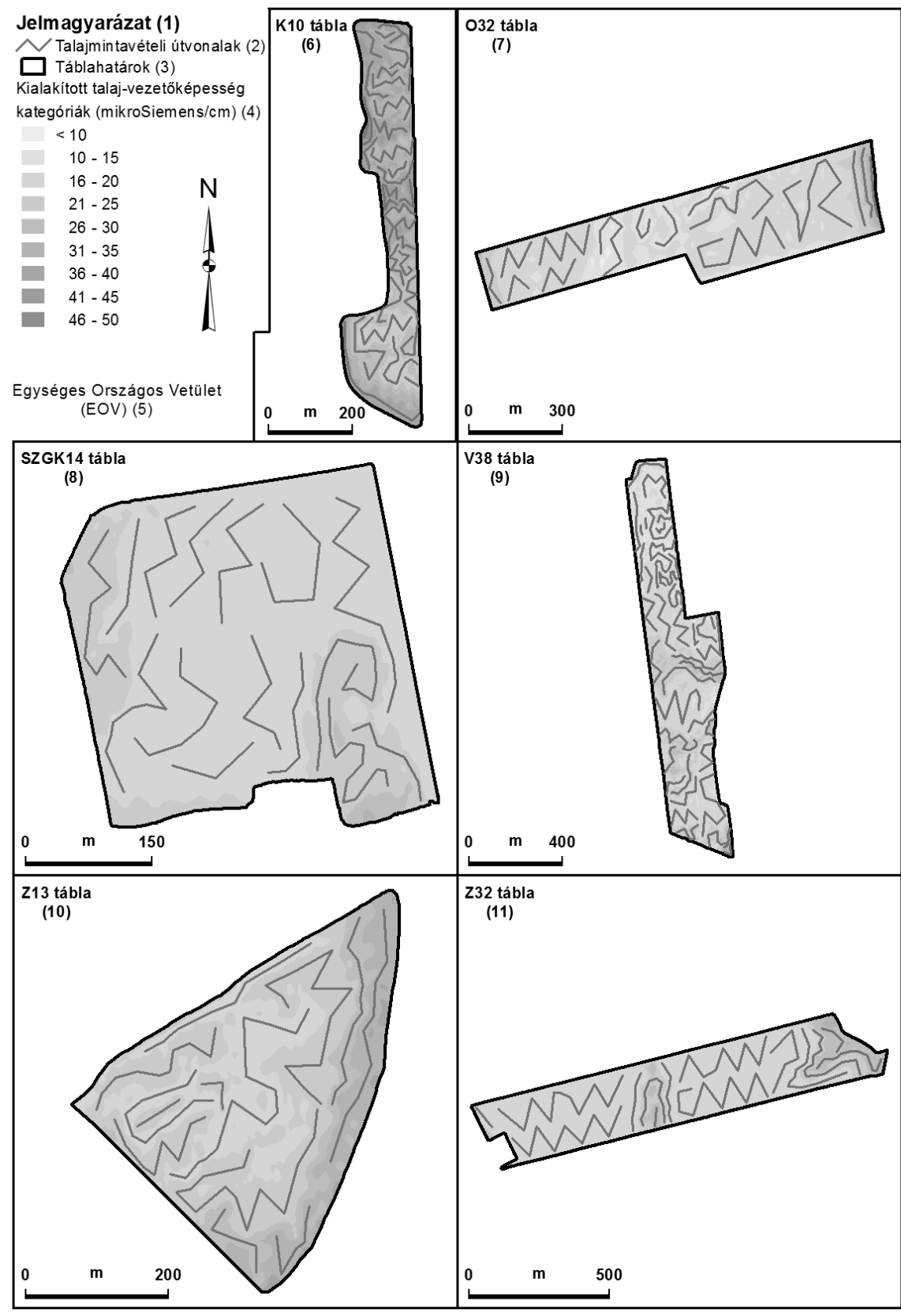

\section{2. ábra}

A táblákon lehatárolt művelési zónák alapján kijelölt talajmintavételi útvonalak 
A mintavételi útvonalak körül $5 \mathrm{~m}$ sugarú puffer zónát képeztünk, amelyekhez a talajszkennerrel mért értékeket rendeltük. Mivel egy-egy puffer zóna területéhez több mért érték is tartozott, ezért zónastatisztika segítségével meghatároztuk a két (50 és $100 \mathrm{~cm}$ ) talajmélység vezetőképességének a puffer zónánkénti átlagát, szórását és varianciáját.

Az adatok eloszlását boxplot diagrammal ellenőriztük, a kiugró értékeket eltávolítottuk. A kiugró értékek eltávolítása után kiszámoltuk a talajparaméterekre mért értékek átlagát és szórását. A szórásértékek másfélszeresét negatív és pozitív irányban jelöltük a mért értékek átlagértékén. A másfélszeres szórásértékeken mindkét irányban kívül eső talajvizsgálati eredményeket kizártuk a további statisztikai vizsgálatokból.

A talajparaméterek vezetőképességgel mutatott kapcsolatát stepwise lineáris regresszió-elemzéssel vizsgáltuk. A regresszió-elemzést a hazai talajtani gyakorlatban már régóta használt, - a talajvizsgálatok körének: alap, bővített és teljeskörü - felosztása szerint végeztük (BARANYAI et al. 1987).

A talajszkennerrel méterben mért tengerszint feletti magasságot (tszfm) minden esetben bevettük a lehetséges magyarázó változók közé. Az „a” esetben (alapvizsgálatok) talajtulajdonságokat lényegesen jellemző fontosabb (kötöttség, kémhatás, humusz- és mésztartalom) talajparaméterek; a „b” esetben (bővített vizsgálatok) alap talajparaméterek és makro tápanyagok (NPK ellátottság); a „,c” esetben (teljeskörü vizsgálatok) alap talajparaméterek, makro- és mikro tápanyagok $\left(\mathrm{Mg}^{2+}, \mathrm{Na}^{+}, \mathrm{Zn}^{2+}, \mathrm{Cu}^{2+}, \mathrm{Mn}^{2+}, \mathrm{SO}_{4}{ }^{2-}, \mathrm{Fe}^{2+}+\mathrm{Fe}^{3+}\right)$ szerinti felosztásban végeztük el az elemzéseket.

A különböző csoportosítás szerinti regressziós elemzésekkel arra voltunk kíváncsiak, hogy a talajparaméterek körének bővitésével szorosabb összefüggéseket kapunk-e az EC értékek és a talajjellemzők között.

A vektoros térinformatikai műveleteket, az adatok térbeli elemzését az ESRI ArcGIS 10.0 térinformatikai szoftverrel végeztük. A statisztikai vizsgálatokhoz az IBM SPSS Statistics 20 programot használtunk.

\section{Eredmények}

Mivel a mintaterület a somogyi dombvidéken barna erdőtalajokon, kilúgzó vízgazdálkodási talajtípusokon helyezkedik el, illetve a korrelációelemzés eredménye is azt mutatta, hogy a táblákon a vízoldható összes sótartalomnak nincs hatása a termőhelyi viszonyok kialakításában, ezért ezt a talajparamétert nem vontuk be a regresszió analízisbe. (A sótartalomnak kiemelkedő szerepe a síkvidéken alföldi és kisalföldi területeken van, ahol szikes talajok alakultak ki, illetve a mélyben sós talajrétegek vagy geogén háttérből eredő nagy sótartalmú talajvizek fordulnak elö.)

Vizsgálati eredmények azt mutatják, hogy az „a” esetben (alap talajvizsgálatok) az $50 \mathrm{~cm}$ mélységben mért talaj-vezetőképesség 6 táblából 5-ben szignifikáns, negatív korrelációt mutat a tengerszint feletti magassággal (3. táblázat). A kötöttség az EC-vel két táblában pozitív, egy táblában pedig negatív korrelációjú. A pH egy esetben (K10 táblában) negatív, a mésztartalom pedig szintén egy esetben (SZGK14 
táblában) pozitív korrelációjú a vezetőképességgel. A SZKG14 táblában a kötöttség és az EC közötti negatív korrelációt a szántón belüli nagy mésztartalmú (10,1-25,0\%) talajváltozati foltok okozzák. Vályog és agyagos vályog fizikai féleség esetén a nagy $\mathrm{CaCO}_{3}$-tartalom megnöveli a talaj-vezetőképességét. A kötöttség hatását ily módon elfedi (pufferolja), mivel a talajrészecskék felületét a karbonát a nagy molekulasúllyal rendelkező szervesanyagokkal együtt organo-minerál komplexeket képezve hidrofóbizálja (LEE et al. 2005; JIN et al. 2014), ami megváltoztatja a talajszemcsék elektromos vezetési tulajdonságait.

Megfigyelhető, hogy az „a” esetben az $50 \mathrm{~cm}$-en mért talaj-vezetőképesség és pl. az Arany-féle kötöttség, a mésztartalom és a kémhatás között akkor mutatható ki szignifikáns összefüggés, vagy gyenge kapcsolat, ha az adott (K10, O32 és SZGK14) táblán kevésbé kapnak szerepet a talajviszonyok kialakításában a domborzati tényezők. Ezt a megállapítást jól igazolják az adott statisztikai jellemzőket mutató táblákon belüli szintkülönbségek.

A $100 \mathrm{~cm}$ mélységben egyértelmủen kimutatható a kapcsolat az EC és a talajtermékenységet befolyásoló talajtulajdonságok a kötöttség, a pH és a mésztartalom között. A mélyebben fekvő talajrétegek ugyanis jobban megőrzik a nedvességet, mint a müvelt feltalaj és így a $100 \mathrm{~cm}$-en mért talaj-vezetöképesség is nagyobb.

Három táblában egyértelműen kimutatható összegfüggés és vizsgálatunk megbízhatóságának kismértékủ, de szignifikáns javulása, ha a számításokba az NPK tápanyag-ellátottságot („,b” eset) is figyelembe vettük (3. táblázat). A K10 tábla 50 cm-es talajmélységében az EC és a foszforellátottság, valamint az O32 és Z32 tábla EC és az ásványi nitrogén ellátottsága között találtunk összefüggést. A K10 tábla esetében $100 \mathrm{~cm}$-es mélységben, - a foszfortartalmon kívül - kapcsolatot mutattunk ki a mért értékek és nitrogén, valamint a talaj EC értéke és kálium ellátottsága között.

A ,„c" esetben (teljesköruß talajvizsgálatoknál) a nyomelemek is szerepeltek a regresszióanalízisben az összefüggések megbízhatósága növekedett, de a „b” esetben tapasztalthoz képest kisebb mértékben. Az $50 \mathrm{~cm}$-es talajmélységben a K10 jelủ táblában a szulfáttartalom, az $\mathrm{O} 32$ jelü táblában pedig a vastartalom korrelált szignifikánsan a talaj-vezetőképességgel. A $100 \mathrm{~cm}$-es talajmélységben a mikroelemek és a talaj-vezetőképesség között a kimutatható kapcsolatok száma kettővel növekedett: összefüggés áll fenn a K10 tábla cink-, nátrium-, szulfát- és vastartalma, illetve az EC értéke között (3. táblázat). Szintén kapcsolat figyelhető meg az O32 tábla mangán és EC, illetve réz és EC értéke között. Az SZGK14 tábla réz és EC-, valamint a V38 tábla nátrium és $\mathrm{EC}$ értéke között. Az összefüggések számának tapasztalt növekedése az $1 \mathrm{~m}$-es mélység nedvesség viszonyaival és agyagtartalma növekedésével magyarázható.

A talajoldatban ionos formában nagy mennyiségben jelen vannak a mikro tápelemek, amelyek hatására a talajok vezetőképessége megnő. A cink- és szulfáttartalom, az EC értékekkel pozitív kapcsolatban van. A mangán- és nátriumtartalom az EC-vel negatív, míg a réz- és a vas nyomelem a táblák helyétől függően negatív, vagy pozitív kapcsolatot mutat, amely erősen függnek a talajtulajdonságoktól és a domborzati viszonyoktól. 
3. táblázat

A zimányi mintaterület mezőgazdasági tábláin mért talaj-vezetőképesség és a talajparaméterek összefüggés-vizsgálatának eredményei

\begin{tabular}{|c|c|c|c|c|c|c|}
\hline 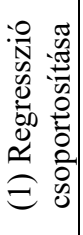 & 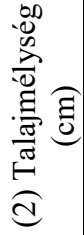 & 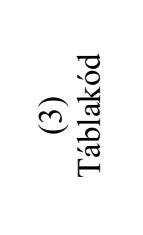 & $\begin{array}{c}\text { (4) } \\
\text { Talajparaméter }\end{array}$ & 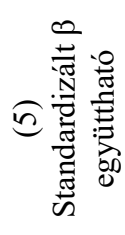 & 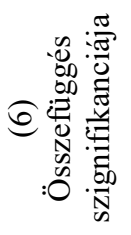 & $\mathrm{R}^{2}$ \\
\hline \multirow{12}{*}{ 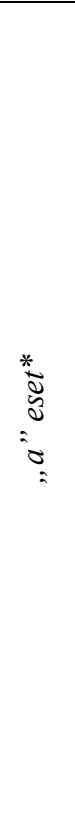 } & \multirow{6}{*}{50} & K10 & $\begin{array}{c}\text { Átlagos tszfm (m)**** } \\
\mathrm{pH}_{(\mathrm{KCl})} \\
\mathrm{K}_{\mathrm{A}}\end{array}$ & $\begin{array}{r}-0,722 \\
-0,546 \\
0,311\end{array}$ & $\begin{array}{l}0,000 \\
0,000 \\
0,013\end{array}$ & 0,583 \\
\hline & & O32 & $\begin{array}{l}\text { Átlagos tszfm (m) } \\
\mathrm{K}_{\mathrm{A}}\end{array}$ & $\begin{array}{r}-0,939 \\
0,547 \\
\end{array}$ & $\begin{array}{l}0,008 \\
0,046\end{array}$ & 0,800 \\
\hline & & SZGK14 & $\begin{array}{c}\mathrm{CaCO}_{3}(\%) \\
\mathrm{K}_{\mathrm{A}}\end{array}$ & $\begin{array}{r}0,542 \\
-0,516 \\
\end{array}$ & $\begin{array}{l}0,015 \\
0,019\end{array}$ & 0,490 \\
\hline & & $\mathrm{V} 38$ & Átlagos tszfm (m) & 0,572 & 0,002 & 0,299 \\
\hline & & Z13 & Átlagos tszfm (m) & $-0,895$ & 0,003 & 0,767 \\
\hline & & $\mathrm{Z32}$ & Átlagos tszfm (m) & $-0,772$ & 0,003 & 0,555 \\
\hline & \multirow{6}{*}{100} & K10 & $\begin{array}{c}\mathrm{K}_{\mathrm{A}} \\
\text { Átlagos tszfm }(\mathrm{m}) \\
\mathrm{pH} \\
(\mathrm{KCl})\end{array}$ & $\begin{array}{r}0,369 \\
-0,660 \\
-0,538\end{array}$ & $\begin{array}{l}0,004 \\
0,000 \\
0,000\end{array}$ & 0,570 \\
\hline & & $\mathrm{O} 32$ & $\begin{array}{c}\text { Atlagos tszfm (m) } \\
\mathrm{K}_{\mathrm{A}}\end{array}$ & $\begin{array}{r}-0,968 \\
0,502\end{array}$ & $\begin{array}{l}0,005 \\
0,045\end{array}$ & 0,835 \\
\hline & & SZGK14 & $\begin{array}{c}\mathrm{K}_{\mathrm{A}} \\
\mathrm{CaCO}_{3}(\%)\end{array}$ & $\begin{array}{r}-0,571 \\
0,566\end{array}$ & $\begin{array}{l}0,006 \\
0,006\end{array}$ & 0,593 \\
\hline & & V38 & $\begin{array}{l}\text { Atlagos tszfm (m) } \\
\mathrm{pH}_{(\mathrm{KCl})}\end{array}$ & $\begin{array}{l}0,814 \\
0,335\end{array}$ & $\begin{array}{l}0,000 \\
0,013\end{array}$ & 0,627 \\
\hline & & Z13 & Átlagos tszfm (m) & $-0,908$ & 0,002 & 0,795 \\
\hline & & Z32 & Átlagos tszfm (m) & $-0,828$ & 0,001 & 0,653 \\
\hline \multirow{7}{*}{ 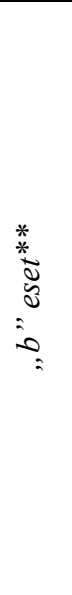 } & \multirow{6}{*}{50} & K10 & $\begin{array}{l}\text { Átlagos tszfm (m) } \\
\text { pH }(\mathrm{KCl}) \\
\mathrm{P}_{2} \mathrm{O}_{5}\left(\mathrm{mg} \mathrm{kg}^{-1}\right)\end{array}$ & $\begin{array}{r}-0,809 \\
-0,496 \\
0,434\end{array}$ & $\begin{array}{l}0,000 \\
0,000 \\
0,000\end{array}$ & 0,672 \\
\hline & & O32 & $\begin{array}{c}\text { Attagos tszfm (m) } \\
\mathrm{NO}_{3}-\mathrm{N}+\mathrm{NO}_{2}-\mathrm{N}\left(\mathrm{mg} \mathrm{kg}^{-1}\right)\end{array}$ & $\begin{array}{r}-1,177 \\
0,710 \\
\end{array}$ & $\begin{array}{l}0,002 \\
0,010\end{array}$ & 0,902 \\
\hline & & SZKG14 & $\begin{array}{c}\mathrm{CaCO}_{3}(\%) \\
\mathrm{K}_{\mathrm{A}}\end{array}$ & $\begin{array}{r}0,542 \\
-0,516\end{array}$ & $\begin{array}{l}0,015 \\
0,019\end{array}$ & 0,490 \\
\hline & & $\mathrm{V} 38$ & Atlagos tszfm (m) & 0,572 & 0,002 & 0,299 \\
\hline & & Z13 & Atlagos tszfm (m) & $-0,895$ & 0,003 & 0,767 \\
\hline & & Z32 & $\begin{array}{c}\text { Átlagos tszfm (m) } \\
\mathrm{NO}_{3}-\mathrm{N}+\mathrm{NO}_{2}-\mathrm{N}\left(\mathrm{mg} \mathrm{kg}^{-1}\right) \\
\end{array}$ & $\begin{array}{r}-0,717 \\
0,528 \\
\end{array}$ & $\begin{array}{l}0,000 \\
0,002 \\
\end{array}$ & 0,842 \\
\hline & 100 & K10 & $\begin{array}{c}\text { Átlagos tszfm (m) } \\
\text { pH }(\mathrm{KCl}) \\
\mathrm{P}_{2} \mathrm{O}_{5}\left(\mathrm{mg} \mathrm{kg}^{-1}\right) \\
\mathrm{NO}_{3}-\mathrm{N}+\mathrm{NO}_{2}-\mathrm{N}\left(\mathrm{mg} \mathrm{kg}^{-1}\right)\end{array}$ & $\begin{array}{r}-0,843 \\
-0,510 \\
0,413 \\
0,231 \\
\end{array}$ & $\begin{array}{l}0,000 \\
0,000 \\
0,001 \\
0,048\end{array}$ & 0,695 \\
\hline
\end{tabular}


3. táblázat folytatása

\begin{tabular}{|c|c|c|c|c|c|c|}
\hline 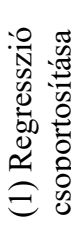 & 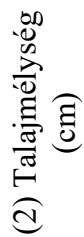 & 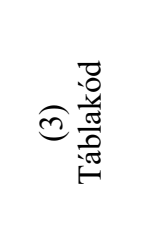 & $\begin{array}{c}\text { (4) } \\
\text { Talajparaméter }\end{array}$ & 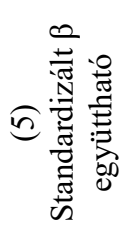 & 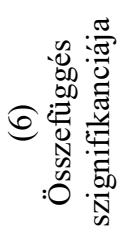 & $\mathrm{R}^{2}$ \\
\hline \multirow{5}{*}{ 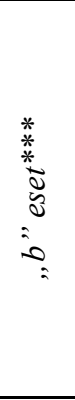 } & \multirow{5}{*}{100} & $\mathrm{O} 32$ & $\begin{array}{c}\text { Átlagos tszfm (m) } \\
\mathrm{NO}_{3}-\mathrm{N}+\mathrm{NO}_{2}-\mathrm{N}\left(\mathrm{mg} \mathrm{kg}^{-1}\right)\end{array}$ & $\begin{array}{r}-1,186 \\
0,652\end{array}$ & $\begin{array}{l}0,001 \\
0,009\end{array}$ & 0,923 \\
\hline & & SZGK14 & $\begin{array}{c}\mathrm{K}_{\mathrm{A}} \\
\mathrm{CaCO}_{3}(\%)\end{array}$ & $\begin{array}{r}-0,571 \\
0,566\end{array}$ & $\begin{array}{l}0,006 \\
0,006\end{array}$ & 0,593 \\
\hline & & V38 & $\begin{array}{l}\text { Átlagos tszfm (m) } \\
\mathrm{pH}_{(\mathrm{KCl})}\end{array}$ & $\begin{array}{l}0,814 \\
0,335\end{array}$ & $\begin{array}{l}0,000 \\
0,013\end{array}$ & 0,627 \\
\hline & & Z13 & Átlagos tszfm (m) & $-0,908$ & 0,002 & 0,795 \\
\hline & & Z32 & $\begin{array}{c}\text { Âtlagos tszfm (m) } \\
\mathrm{NO}_{3}-\mathrm{N}+\mathrm{NO}_{2}-\mathrm{N}\left(\mathrm{mg} \mathrm{kg}^{-1}\right) \\
\mathrm{K}_{2} \mathrm{O}\left(\mathrm{mg} \mathrm{kg}^{-1}\right)\end{array}$ & $\begin{array}{r}-0,886 \\
0,505 \\
-0,259\end{array}$ & $\begin{array}{l}0,000 \\
0,000 \\
0,023\end{array}$ & 0,920 \\
\hline \multirow{9}{*}{$\begin{array}{l}\widetilde{v} \\
\vdots \\
= \\
\vdots \\
\vdots\end{array}$} & \multirow{6}{*}{50} & K10 & $\begin{array}{c}\text { Átlagos tszfm (m) } \\
\text { pH }{ }_{(\mathrm{KCl})} \\
\mathrm{P}_{2} \mathrm{O}_{5}\left(\mathrm{mg} \mathrm{kg}^{-1}\right) \\
\mathrm{SO}_{4}{ }^{2-}\left(\mathrm{mg} \mathrm{kg}^{-1}\right)\end{array}$ & $\begin{array}{r}-0,772 \\
-0,530 \\
0,327 \\
0,313 \\
\end{array}$ & $\begin{array}{l}0,000 \\
0,000 \\
0,003 \\
0,003\end{array}$ & 0,754 \\
\hline & & $\mathrm{O} 32$ & $\begin{array}{c}\mathrm{Fe}^{2+}+\mathrm{Fe}^{3+}\left(\mathrm{mg} \mathrm{kg}^{-1}\right) \\
\mathrm{P}_{2} \mathrm{O}_{5}\left(\mathrm{mg} \mathrm{kg}^{-1}\right)\end{array}$ & $\begin{array}{r}-0,901 \\
0,437\end{array}$ & $\begin{array}{l}0,000 \\
0,008\end{array}$ & 0,750 \\
\hline & & SZGK14 & $\begin{array}{c}\mathrm{CaCO}_{3}(\%) \\
\mathrm{K}_{\mathrm{A}}\end{array}$ & $\begin{array}{r}0,542 \\
-0,516\end{array}$ & $\begin{array}{l}0,015 \\
0,019\end{array}$ & 0,490 \\
\hline & & V38 & $\begin{array}{c}\mathrm{pH}_{(\mathrm{KCl})} \\
\text { Átlagos tszfm (m) }\end{array}$ & $\begin{array}{l}0,587 \\
0,537\end{array}$ & $\begin{array}{l}0,000 \\
0,000\end{array}$ & 0,403 \\
\hline & & Z13 & Átlagos tszfm (m) & $-0,872$ & 0,000 & 0,737 \\
\hline & & $\mathrm{Z} 32$ & $\begin{array}{c}\text { Átlagos tszfm (m) } \\
\mathrm{NO}_{3}-\mathrm{N}+\mathrm{NO}_{2}-\mathrm{N}\left(\mathrm{mg} \mathrm{kg}^{-1}\right) \\
\mathrm{P}_{2} \mathrm{O}_{5}\left(\mathrm{mg} \mathrm{kg}^{-1}\right)\end{array}$ & $\begin{array}{r}-1,034 \\
0,477 \\
-0,421\end{array}$ & $\begin{array}{l}0,000 \\
0,001 \\
0,048\end{array}$ & 0,870 \\
\hline & \multirow{3}{*}{100} & K10 & $\begin{array}{c}\mathrm{Zn}^{2+}\left(\mathrm{mg} \mathrm{kg}^{-1}\right) \\
\mathrm{Na}^{+}\left(\mathrm{mg} \mathrm{kg}^{-1}\right) \\
\mathrm{SO}_{4}{ }^{2-}\left(\mathrm{mg} \mathrm{kg}^{-1}\right) \\
\text { Átlagos tszfm (m) } \\
\mathrm{Fe}^{2+}+\mathrm{Fe}^{3+}\left(\mathrm{mg} \mathrm{kg}^{-1}\right)\end{array}$ & $\begin{array}{r}0,426 \\
-0,353 \\
0,491 \\
-0,414 \\
0,409 \\
\end{array}$ & $\begin{array}{l}0,001 \\
0,004 \\
0,000 \\
0,000 \\
0,000\end{array}$ & 0,779 \\
\hline & & $\mathrm{O} 32$ & $\begin{array}{l}\mathrm{Mn}^{2+}\left(\mathrm{mg} \mathrm{kg}^{-1}\right) \\
\mathrm{Cu}^{2+}\left(\mathrm{mg} \mathrm{kg}^{-1}\right) \\
\text { Átlagos tszfm }(\mathrm{m})\end{array}$ & $\begin{array}{r}-1,018 \\
0,573 \\
-0,383\end{array}$ & $\begin{array}{l}0,000 \\
0,006 \\
0,012\end{array}$ & 0,809 \\
\hline & & SZGK14 & $\begin{array}{c}\mathrm{K}_{\mathrm{A}} \\
\mathrm{Cu}^{2+}\left(\mathrm{mg} \mathrm{kg}^{-1}\right)\end{array}$ & $\begin{array}{l}-0,720 \\
-0,613\end{array}$ & $\begin{array}{l}0,001 \\
0,003\end{array}$ & 0,633 \\
\hline
\end{tabular}


3. táblázat folytatása

\begin{tabular}{|c|c|c|c|c|c|c|}
\hline 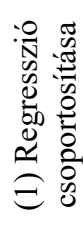 & 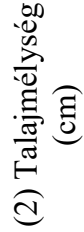 & 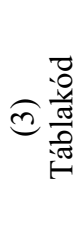 & $\begin{array}{c}\text { (4) } \\
\text { Talajparaméter }\end{array}$ & 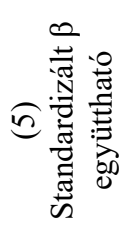 & 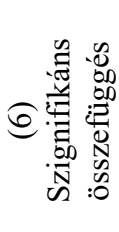 & $\mathrm{R}^{2}$ \\
\hline \multirow{3}{*}{ 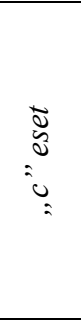 } & \multirow{3}{*}{100} & V38 & $\begin{array}{c}\text { Átlagos tszfm (m) } \\
\mathrm{pH}_{(\mathrm{KCl})} \\
\mathrm{K}_{\mathrm{A}} \\
\mathrm{Na}^{+}\left(\mathrm{mg} \mathrm{kg}^{-1}\right)\end{array}$ & $\begin{array}{r}0,782 \\
0,568 \\
0,261 \\
-0,216 \\
\end{array}$ & $\begin{array}{l}0,000 \\
0,000 \\
0,011 \\
0,038\end{array}$ & 0,652 \\
\hline & & $\mathrm{Z13}$ & Átlagos tszfm (m) & $-0,903$ & 0,000 & 0,798 \\
\hline & & $\mathrm{Z32}$ & $\begin{array}{c}\text { Átlagos tszfm (m) } \\
\mathrm{NO}_{3}-\mathrm{N}+\mathrm{NO}_{2}-\mathrm{N}\left(\mathrm{mg} \mathrm{kg}^{-1}\right) \\
\mathrm{P}_{2} \mathrm{O}_{5}\left(\mathrm{mg} \mathrm{kg}^{-1}\right)\end{array}$ & $\begin{array}{r}-1,122 \\
0,403 \\
-0,436\end{array}$ & $\begin{array}{l}0,000 \\
0,001 \\
0,015\end{array}$ & 0,917 \\
\hline
\end{tabular}

Megjegyzés: *Alap talajvizsgálatok (kötöttség, humusztartalom, kémhatás, mésztartalom). **Bővített talajvizsgálatok (alap talajvizsgálatok és makro (NPK) tápanyag-vizsgálatok). ***Teljeskörü talajvizsgálatok (alap talajvizsgálatok, makro tápanyag-vizsgálatok és mikro $\left(\mathrm{Mg}^{2+}, \mathrm{Na}^{+}, \mathrm{Zn}^{2+}, \mathrm{Cu}^{2+}, \mathrm{Mn}^{2+}, \mathrm{SO}_{4}^{2-}, \mathrm{Fe}^{2+}+\mathrm{Fe}^{3+}\right)$ tápanyag-vizsgálatok). ****Átlagos tengerszint feletti magasság $(\mathrm{m})$.

\section{Vizsgálati eredmények megvitatása és következtetések}

Vizsgálataink alapján általánosságban elmondható, hogy mindhárom regressziós felosztásban a mintaterület tábláin a tengerszint feletti magasság csökkenésével arányosan nő a talaj-vezetőképessége, illetve a mért értékek növekedésével nő a talajok kötöttsége, azaz agyagtartalma. A vizsgált dombsági területeken a talajváltozati foltok, azaz a lehatárolt termőhelyi zónák termékenységi viszonyait nemcsak az elsődleges talajtulajdonságok (textúra, kémhatás, humusz- és mésztartalom) határozzák meg, hanem azokkal együtt azt a domborzati viszonyok is befolyásolják és/vagy módosítják. A domborzati viszonyok elsősorban a táblákon vagy a parcellákon belüli tengerszint feletti magasság különbségekben nyilvánulnak meg.

Általában a szakirodalmi adatok (SUDDUTH et al., 2001; KORSAETH 2006; Peralta et al., 2013; PIIKKI et al., 2013; HeIL \& SCHMIDHALTER 2017) alapján a talaj vezetőképessége a talajnedvesség-tartalomtól, talajok fizikai feleségétől és a talajszerkezetétől is függ. A nagyobb agyagtartalmú talajféleségek illetve talajrétegek vízmegkötö képessége és víztartalma nagyobb, mint a homok- vagy homokos vályog talajoké. A nedvesebb talaj EC-je is nagyobb. A tapasztalatok szerint a dombvidéki szántókon a csapadék felszín alatti és felszíni lefolyással a völgytalpi mélyedésekben gyülik össze. Az erodált domboldalak és dombvállak talajfoltjai, rossz vízgazdálkodásuk miatt hamar kiszáradnak. Az erózió hatására a dombok között a mélyen fekvő területeken jórészt agyagos fizikai féleségű lejtőhordalék és réti jellegủ talajok alakulnak ki. Vízgazdálkodásuk általában kedvezőbb, mint az erodált 
területeké. Ezt kiválóan mutatja a talaj-vezetőképessége és tengerszint feletti magasságának szignifikánsan negatív összefüggése. A táblán belüli nagy térbeli szintkülönbségek (2. táblázat) a domborzati viszonyokra és a terület erodáltságára utalnak, amelyek alakítják a termőhelyi zónák talajtani sajátosságait.

Az EC és a karbonát-tartalom, illetve az EC és a kémhatás között is felfedezhető kapcsolat. A $\mathrm{CaCO}_{3}$-tartalom segíti a talaj szerkezetességének kialakulását (porhanyós, apró morzsás szerkezet), ami befolyásolja a vízgazdálkodási tulajdonságokat is. A vízgazdálkodási tulajdonságok javulása kedvezőbb nedvesség állapotot eredményez, amikor a talajoldatban több ion áramlik szabadon, ami az EC növekedéséhez vezet. A mésztartalomtól nagyban függ a talajok kémhatása. A meszes talajváltozatoknak a növénytermesztés számára kedvező, semleges körüli a $\mathrm{pH}-\mathrm{ja}$.

Az eredmények szerint a jó víz- és tápanyag-ellátottságnak fontos szerepe van a talajfoltok vagy művelési zónák termékenységi viszonyaiban. Az 1 m-es talajmélységben a talaj-vezetőképesség és a mért talajparaméterek között szorosabb összefüggéseket tudtunk kimutatni, mint a fél méteres vizsgálatok esetén, ezt támasztja a mélyebb talajmélységben az $\mathrm{R}^{2}$ értékek növekedése is. Jól mutatja azt, hogy a domborzati viszonyok jelentősen befolyásolják a talajokban - a nedvességtartalom vertikális eloszlásán keresztül - a tápanyagok mozgását és felhalmozódását. A dombvidéki szántókon a magasabb területekröl, a lejtőkről a csapadékkal a mélyebben fekvő helyekre mosódnak le a tápanyagok. Azok a völgytalpakban halmozódnak fel a talajokban és eredményeznek azok alsó rétegeiben magasabb tápanyagszintet. Tehát a talajok tápanyag-gazdálkodását a domborzati viszonyok is befolyásolják. Mindezek megmutatkoznak az N és a P tápanyag-ellátottság és a mért EC értékek közötti összefüggésekben.

A talaj-vezetöképessége és a mikroelemek közötti kapcsolatok statisztikai eredményeire jelenleg kevéssé tudunk magyarázatot adni. Továbbá a talajellenállás és a makro tápanyagok közötti összefüggések, felderítéséhez és megértéséhez további vizsgálatokra, illetve a talajadatbázis bővítése szükséges. Vizsgálataink alapján elmondható, hogy azon táblákon, ahol a talaj agyagtartalma jelentős (fizikai félesége agyagos vályog és agyag), vagy az agyagosság a mélyebben fekvő talajszintekben $(100 \mathrm{~cm}-\mathrm{en})$ is megjelenik, ott csak igen gyenge kapcsolatot mutattunk ki a talaj-vezetőképessége és a mikro tápelemek között. Ezt megmagyarázza, hogy a nagy fajlagos felületü agyagszemcsék és agyaghártyák jelentős mennyiségben kötnek meg mikroelemeket. Ez lehet az oka, hogy hasonlóan a nagy $\mathrm{CaCO}_{3}$-tartalmú talajfoltok esetében, (lásd „c” eset) a mikro tápanyagtartalom hatását a kötöttség pufferolja.

A vizsgálatra kiválasztott táblák talajszkennelése 2019 tavaszán száraz, vízhiányos időszakban történt. Ezt igazolja a zimányi mintaterület központi részére havi hömérsékleti $\left({ }^{\circ} \mathrm{C}\right)$ és csapadékmennyiség $(\mathrm{mm})$ adatsorokból számított éves természetes növényi vízellátottság (SzÁsz 1991), és a Pálfai-féle aszályindex (PÁLFAI 2004). Ezek szerint a 2019-es év igen száraznak minősül a talajnedvességtartalom szempontjából.

A talajok vezetőképességének mérése valóban elérhető, gyors és egyszerü módszer, amely a laboratóriumban mért „hagyományos” talajvizsgálati 
eredményekkel együtt a termőhelyi zónalehatárolás alapját képezheti. A jövőben folytatni kell az ilyen irányú vizsgálatokat más termőterületeken és egyre bővülő talajadatbázison. A statisztikai elemzésekkel tovább pontosíthatjuk és finomíthatjuk a szántókon mért talaj-vezetőképességén alapuló becslőmodell megbízhatóságát.

A tervezett szántóföldi EC méréseken alapuló talajtulajdonságok vizsgálatoknál mindenképpen azt figyelembe kell, hogy az adott mintaterületen - a vegetációs időszakot tekintve - az egyes talajrétegek folyamatos és állandó nedvesség viszonyait. A mért vezetőképesség értékeket a talaj pillanatnyi nedvességtartalma, vízellátottsága határozza meg. Vizsgálni kell az évjárathatások szerepét is, hiszen a különbözö, - pl. száraz, normál és csapadékos - évjárat-típusok is jelentősen meghatározzák a talajok aktuális állapotát, így a mért EC-t is. Az évjárat-típusok megállapításához szükség van különböző természetes növényi vízellátottságot vagy vízhiányt mutató indexek kiszámítására, amelyekhez a mintaterületekre megbízható, több éves havi, vagy dekád szintủ (10 napos) időjárási adatsorok kellenek.

\section{Összefoglalás}

Vizsgálatunk célja az volt, hogy egy Somogyban elhelyezkedő, dombvidéki mintaterület szántóin elemezzük a mért talaj-vezetöképesség (EC) értékek és lehatárolt termőhelyi (művelési) zónák talajtulajdonságai közötti összefüggéseket. A vizsgált szántóterületek löszön kialakult, típusos Ramann-féle barna erdőtalajon és karbonátos csernozjom barna erdőtalajon helyezkednek el. Feltalajuk döntően vályog és agyagos vályog fizikai féleségü. A talaj vezetőképességét 50 és $100 \mathrm{~cm}$-es talajmélységben mértük.

A mintaterület talajadatait térinformatikai állományba foglaltuk, az adatok rendezését és azok összekapcsolását az ESRI ArcGIS 10.0 programmal végeztük el. A táblák heterogenitását mutató laboratóriumi talajvizsgálatok eredményeit a mért EC értékekkel összevetettük, amelyhez az IBM SPSS Statistics 20 szoftver segítségével stepwise-típusú lineáris regressziót alkalmaztunk. A regressziókat a talajvizsgálatok csoportosításával megegyezően: alap („a” eset), bővített („b” eset) és teljeskörü („,e”eset) alapján futtattuk le. A számításoknál az „a” eset a talajtulajdonságokat meghatározó fontosabb talajparaméterek (kötöttség, humusz- és mésztartalom, kémhatás), a „b” eset az alap talajparamétereket és a makro tápanyagok (NPK ellátottságot), valamint a „, ” eset az előző kettőt és mikro tápanyagok $\left(\mathrm{Mg}^{2+}, \mathrm{Na}^{+}, \mathrm{Zn}^{2+}, \mathrm{Cu}^{2+}, \mathrm{Mn}^{2+}, \mathrm{SO}_{4}{ }^{2-}, \mathrm{Fe}^{2+}+\mathrm{Fe}^{3+}\right)$ körét jelenti.

A különböző csoportosításban elvégzett elemzések során arra voltunk kíváncsiak, hogy a vizsgálati talajparaméterek körének változtatásával szorosabb kapcsolatokat találunk-e a mért átlagos EC értékek és a talajtulajdonságok között. Az eredményeink által kaphatunk-e olyan kellő pontosságú és megbízhatóságú becslömodellt, amely a talajok térbeli heterogenitását megmutatja az EC értékek alapján, így a módszer nagyban meggyorsíthatja és leegyszerüsítheti a „hagyományos” talajvizsgálatokhoz képest a termőhelyi zónák elkülönítését.

A vizsgálati eredményeink alapján elmondható, hogy mindhárom regressziós csoportosítás esetén a tengerszint feletti magasság csökkenésével arányosan nő a talaj-vezetőképesség, illetve az EC értékek növekedésével nő a talajok kötöttsége, 
amellyel együtt növekszik az agyagtartalom is. Ez a folyamat $100 \mathrm{~cm}$-es talajmélységben a nagyobb víztartalom miatt eröteljesebben jelentkezik, mint az $50 \mathrm{~cm}$-es talajmélységben. A termőhelyi zónák termékenységi viszonyait az elsődleges talajtulajdonságokon, illetve a makro és a mikro tápanyag-ellátottságokon kívül a domborzati viszonyok is módosíthatják. A talajellenállás mérése bárki számára elérhető, gyors és egyszerü módszer. A laboratóriumi talajvizsgálatokat kiegészítve alkalmas arra, hogy a precíziós növénytermesztésben segítséget nyújtson a termőhelyi zónák lehatárolásában.

Kulcsszavak: precíziós gazdálkodás, talaj-vezetőképesség, talajparaméterek, térbeli talajheterogenitás, termőhelyi zónalehatárolás

\section{Köszönetnyilvánítás}

A kutatás a GINOP-2.2.1-15-2017-00105 azonosító számú az „Innovációs folyamatot támogató szolgáltatások fejlesztése a szántóföldi növénytermesztés számára (SMART-GAZDA)" címü projekt anyagi támogatásával zajlik. A projekt a Széchenyi 2020 program keretében valósul meg. A publikáció elkészítését az EFOP3.6.3-VEKOP-16-2017-00008 számú projekt támogatta. Köszönet az EFOP-3.6.116-2016-00015 projekt anyagi támogatásáért. A projekt az Európai Unió támogatásával, az Európai Szociális Alap társfinanszírozásával valósult meg. A vizsgálat az Európai Unió támogatásával a „SIEUSOIL - Sino-EU Soil Observatory for Intelligent Land Ide Management" címü és 818346 azonosító számú H2020 projekt keretében történt.

\section{Irodalomjegyzék}

ALLEN, R. D., 1977. Evaluation of arial photography as technique for estimating citrus fruit yield. U.S. Department of Agriculture Staff Report, Statistical reporting service.

AmBrus, A., 2016. A hely-specifikus tápanyag-ellátás és az őszi búza (Triticum aestivum L.) mennyiségi és minőségi jellemzői közötti összefüggések vizsgálata. Doktori (PhD) értekezés. Szent István Egyetem, Mezőgazdaság- és Környezettudományi Kar, Növénytermesztési Intézet, Gödöllő.

Baranyai, F., FeKete, A. \& KovÁCS, I., 1987. A magyarországi tápanyagvizsgálatok eredményei. Mezőgazdasági Kiadó. Budapest.

CORWIN, D. L. \& LESCH, S. M., 2003. Application of soil electrical conductivity to precision agriculture: theory, principles and guidelines. Agronomy Journal. 95. 455-471. 
DöVÉNYI, Z. (Szerk.), BECSE, A., MEZÖSI, G., ÁDÁM, L., JuHÁSZ, Á., MAROSI, S., SOMOGYI, S., SZILÁRD, J., AMBRÓZY, P., KONKOlYNÉ BIHARI, Z., KIRÁlY, G., MOLNÁR, Z., BÖLÖNI, J., CSIKY, J., VOJTKÓ, A., RAJKAI, K., TÓTH, G., TINER, T., MichalKó, G. \& KereszTeSI, Z., 2010. Magyarország kistájainak katesztere. Második, átdolgozott és bővített kiadás. MTA Földrajztudományi Kutatóintézet, Budapest.

GULÁCSI A. \& KovÁCS F., 2015. Aszályvizsgálat lehetősége Modis műholdképekből számított spektrális indexekkel Magyarországon. Tájökológiai Lapok. 13. (2) 235-248.

GYŐRFFY, B., 2000. A biogazdálkodástól a precíziós mezőgazdaságig. Gyakorlati Agrofórum, 11. (2) 1-5.

HeIL, K. \& SCHMIDHAlteR, U., 2017. The Application of EM38: Determination of Soil Parameters, Selection of Soil Sampling Points and Use in Agriculture and Archaeology - Review. Sensors. 17. 1-44.

HERMANN, T., KISMÁNYOKY, T. \& TÓTH, G., 2014a. A foszfor-ellátottság hatása a kukorica (Zea mays L.) termőképességére mezőségi és barna erdőtalajú termőhelyeken, különbözö évjáratokban. Növénytermelés. 63. (1) 1-18.

HERMANN, T., KISMÁNYOKY, T. \& TÓTH, G., 2014b. A humuszellátottság hatása a kukorica (Zea mays L.) termésére csernozjom és barna erdőtalajú termőhelyeken, különböző évjáratokban. Növénytermelés. 63. (2) 1-22.

JaSSÓ, F. (Szerk.), HORVÁTH, B., IZSÓ, I., KIRÁLY, L., PARÁSZKA, L. \& SZABÓNÉ KELE, G., 1989. '88 útmutató a nagyméretarányú országos talajtérképezés végrehajtásához. Agroinform Kiadó. Budapest.

JENEY, I. \& JASSÓ, F. (Szerk.), 1983. Magyarország genetikus talajtérképe (méretarány: 1:200.000). Kartográfiai Vállalat, Budapest.

JiN, J., ZimMerman, A. R,, MOORE, P. J. \& MARTIN, J. B., 2014. Organic and inorganic carbon dynamics in a karst aquifer: Santa Fe River Sink-Rise system, north Florida, USA. Journal of Geophysical Research: Biogeosciences. 119. (3) 340-357.

Johnson, C. K., Doran, J. W., Wienhold, B. J. \& Shanahan, J. F., 2001. Fieldscale electrical conductivity mapping for delineating soil condition. Soil Science Social American Journal. 65. 1829-1837.

KACHANOSKI, R. G., GregORICH, E. G. \& VAN WeSENBEeCK, I. J., 1988. Estimating spatial variations of soil water content using non contacting electromagnetic inductive methods. Canadian Journal Soil Science. 68. 715-722.

KaffKA, S. R., Lesch, S. M., Bali, K. M. \& CoRwin, D. L., 2005. Site-specific management in salt-affected sugar beet fields using electromagnetic induction. Computers and Electronics in Agriculture. 46. 329-350.

Kocsis, M., BerÉNYI ÜVEgES, J., VÁRsZEGI, G. \& SisÁK, I., 2015. A MÉM NAK genetikus talajtérkép bemutatása és talajosztályozási kategóriáinak elemzése. Agrokémia és Talajtan. 64. (1) 53-72.

KorSAETH, A., 2006. Height above ground corrections of EM38 readings of soil apparent electrical conductivity. Acta Agriculturae Scandinavica Section B-Soil and Plant Science. 56. 333-336. 
LeE, Y. J., Elzinga, E. J. \& ReEDER, R. J., 2005. Cu(II) adsorption at the calcitewater interface in the presence of natural organic matter: kinetic studies and molecular-scale characterization. Geochimica et Cosmochimica Acta. 69. (1) 49-61.

MACHANDA, M., KUDART, M. \& TIWARI, A. K., 2002. Soil survey and mapping using remote sensing. Tropical Ecology. 43. (1) 61-74.

MARTON, J., 2006. Gabonatermesztés jövőjéről a múlt tükrében. http://ikr.hu/tudastar_gabonaterm_ml.php

MELCHIORI, P. Z., 2002. Spatial variability of wheat yield, association with edaphic parameters and assessment of application of nitrogen for specific sites. Thesis for Master of Science degree. National University of Mar del Plata, Balcarce, Argentina.

MeSTERHÁZI, P. Á., 2011. Precíziós növénytermesztés a gyakorlatban. Agrárágazat. 2. 94.

MiLleR, B. A. \& SCHAETZL, R. J., 2014. The historical role of base map sin soil geography. Geoderma. 230-231. 329-339.

Moore, I. D., Gessler, E., Nielsen, G. A. \& Peterson, G. A., 1993. Terrain analysis for soil specific crop management. Second International Conference on Site-Specific Management for Agricultural Systems, Supplement. pp. 27-51.

Moral, F. J., Terrón, J. M. \& MARques DA Silva, J. R., 2010. Delineation of management zones using mobile measurements of soil apparent electrical conductivity and multivariate geostatistical techniques. Soil Tillage Research 106. 335-343.

PÁLFAI, I., 2004. Belvizek, aszályok Magyarországon. Közlekedési Dokumentációs Kft, Budapest.

PÁszTOR, L., Dobos, E., SZATMÁRI, G., LABORCZI, A., TAKÁCS, K., BAKACSI, Z. \& SZABÓ, J., 2014. Application of legacy soil data in digital soil mapping for the elaboration of novel, countrywide maps of soil conditions. Agrokémia és Talajtan. 63. (1) 79-88.

Peralta, N. R., Costa J. L., Balzarini, M. \& Angelini, H., 2013. Delineation of management zones with measurements of soil apparent electrical conductivity in the southeastern pampas. Canadian Journal of Soil Science 93. 205-218.

PIIKKI, K., SÖDERSTRÖM, M. \& STENBERG, B., 2013. Sensor data fusion for topsoil clay mapping. Geoderma. 199. 106-116.

RhoAdes, J. D., MANTEGHI, N. A., Shouse, P. J. \& Alves, W. J., 1989. Soil electrical conductivity and soil salinity: New formulations and calibrations. Soil Science Social American Journal. 53. 433-439.

Scull, P., Franklin, J., Chadwick, O. A. \& MCARThur, D., 2003. Predictive soil mapping: a review. Progress in Physical Geography. 27. (2) 171-197.

Sudduth, K. A., DRUMmond, S. T. \& KitHen, N. R., 2001. Accuracy issues in electromagnetic induction sensing of soil electrical conductivity for precision agriculture. Computers and Elektronics in Agricultulre. 31. 239-264.

Sudduth, K. A., Kitchen, N. R., Bollero, G. A., Bullock, D. G. \& Wiebold, W. J., 2003. Comparison of electromagnetic induction and direct sensing of soil electrical conductivity. Agronomy Journal. 95. 472-482. 
StefanOVITS, P., 1963. Magyarország talajai. Akadémiai Kiadó. Budapest.

SZATMÁRI, G., BARTA, K. \& PÁSZTOR, L., 2015. An application of a spatial simulated annealing sampling optimization algorithm to support digital soil mapping. Hungarian Geographical Bulletin. 64. (1) 35-48.

SzÁsz, G., 1991. A nyári aszályhajlam területi eloszlása Magyarországon. Acta Geographica. XXVIII-XXIX. 291-308.

SzÉKELY, C., 2000. Tervezési módszerek és eljárások. In: BuZÁs, G., NEMESSÁLYI, Zs. \& SzÉKELY, C. (Szerk.): Mezögazdasági üzemtan I. (10. fejezet). Budapest, Mezőgazdasági Szaktudás Kiadó. pp. 272-328.

SZABOlCS, I. (Szerk.), DARAB, K., FóRIZS, J.-NÉ, FÖlDVÁRI, G., JASSÓ, F. \& VÁRAllYAY, G., 1966. A genetikus üzemi talajtérképezés módszerkönyve. Országos Mezőgazdasági Minőségvizsgáló Intézet (OMMI). Budapest.

TAMÁs, J., 2001. Precíziós mezőgazdaság. Mezőgazdasági Szaktudás Kiadó, Budapest.

YE, X. \& SAKAI, K., 2011. Application of airborne hyperspectral imagery to estimating fruit yield in citrus. $3^{\text {rd }}$ Workshop on Hyperspectral Image and Signal Processing: Evaluation in Remote Sensing. Lisbon. Portugal. 6-9 June. 2011.

Yost, R. S., UeHARA, G. \& FoX, R. L., 1982. Geostatistical analysis of soil chemical properties. II. Kriging. Soil Science Social American Journal. 46. 1033-1037.

VÁRALLYAY, G., 2012. Talajtérképezés, talajtani adatbázisok. Agrokémia és Talajtan. 61. Online Suppl. 249-268. http://www.aton.hu/documents/ 10156/c4e78c6b-a2bf-4441-b367-39e2275d83ce

\section{Correlations between soil conductivity and soil properties of crop management zones}

\footnotetext{
${ }^{1 *}$ Mihály KoCsIS, ${ }^{2}$ László MENYHÁRT, ${ }^{3}$ András BenŐ and ${ }^{4}$ Tamás HeRMANN

${ }^{1}$ Department of Sustainability, Hungarian University of Agriculture and Life Sciences, Institute for Environmental Sciences, Georgikon Campus, Keszthely (Hungary); ${ }^{2}$ Hungarian University of Agriculture and Life Sciences, Institute of Technology, Georgikon Campus, Keszthely (Hungary); ${ }^{3}$ Department of Soil Mapping and Environmental Informatics, Institute for Soil Sciences, Centre for Agricultural Research, Budapest (Hungary); ${ }^{4}$ Institute of Advanced Studies, Köszeg (Hungary)
}

\section{Summary}

Our aim was to analyse the relationships between the measured soil electrical conductivity (EC) and the soil properties of different delimited production (tillage) zones in a hillside sample area situated in Somogy county. The examined arable lands are situated in typical Ramann-type brown forest soil and chernozem-brown forest soil mostly with loam and clay loam formed on loess. For the investigations, two soil resistance values (measured at $50 \mathrm{~cm}$ and $100 \mathrm{~cm}$ depth) were used.

Soil data of the sample area were incorporated into a GIS file, the ordering and connection of the data was performed by ESRI ArcGIS 10.0 program. The results of 
the soil laboratory tests (which show soil heterogeneity) were correlated to the measured EC-values with stepwise linear regression using IBM SPSS Statistics 20 software. The regression were run in line with the alignment of soil investigations: basic (case „a"), extended (case „b") and completed (case „, (”). By the calculations, case „a" means the group of the most important soil parameters which are determinative soil characteristics (upper limit of plasticity or $\mathrm{K}_{\mathrm{A}}$, humus-, lime content, $\mathrm{pH}$ ), case „, (NPK-content), while case „, $\mathbf{c}$ " means case „b" plus the group of micronutrients $\left(\mathrm{Mg}^{2+}, \mathrm{Na}^{+}, \mathrm{Zn}^{2+}, \mathrm{Cu}^{2+}, \mathrm{Mn}^{2+}, \mathrm{SO}_{4}^{2-}, \mathrm{Fe}^{2+}+\mathrm{Fe}^{3+}\right)$.

With the analyses made in different alignments our aim was to determine whether with the changing of examined soil parameters there will be tighter relationships between the measured EC-values and soil properties. Further aim was to examine whether it is possible to make a properly accurate and reliable estimation model, which can show the real soil circumstances (spatial heterogeneity of soils) based on EC-values, since this method can accelerate and simplify the separation of productivity zones compared to the conventional soil examinations.

Based on the results it can be concluded that in case of all the three regression groups the electrical conductivity increases proportionally with the decreasing of elevation. Besides, with the increasing of EC-values the $\mathrm{K}_{\mathrm{A}}$ - and with it, the clay content also - increases. This process develops in a more significant way in the depth of $100 \mathrm{~cm}$ than in $50 \mathrm{~cm}$ because of the higher water content. Besides the primary soil characteristics and the amount of macro- and micronutrients, the fertility conditions of the production zones can be affected by the geographical circumstances as well. The measurement of soil resistance is a fast, easy and generally available method, which is suitable - with the completion of laboratory examinations - for giving assistance to delineate the production zones in the precision crop production.

Keywords: precision management, soil conductivity, soil parameters, spatial soil heterogeneity, management zone delimitation

\section{Tables and figures}

Figure 1. Location of the Zimány study area. (1) Legend; (2) Fields of Zimány area; (3) Boundaries of microregion; (4) Unified National Projection System (UNPS, EOV in Hungarian).

Figure 2. Soil sampling routes designated based on the cultivation zones delimited on the fields. (1) Legend; (2) Soil sampling routes; (3) Field boundaries; (4) Soil conductivity categories created $\left.(\mu \mathrm{S} \mathrm{cm})^{-1}\right)$; (5) Unified National Projection System (UNPS, EOV in Hungarian); (6) K10 field; (7) O32 field; (8). SZGK14 field; (9) V38 field; (10) Z13 field; (11) Z32 field.

Table 1. Complete laboratory soil investigation list of soil samples from Zimány fields. (1) Soil parameters examined; (2) Units; (3) Method of determination; (4) Detection limit/Measuring range. 
Table 2. Descriptive statistics of the main measured parameters and the altitudes above sea level (aasl (m)) of the Zimány study area. (1) Field code; (2) Area (ha); (3) Number of cases; (4) Measured properties; (5) Minimum; (6) Maximum; (7) Mean; (8) Standard deviation. Remark: *Altitude (m).

Table 3. Results of correlation investigations between soil conductivity and soil parameters measured on the plots of the Zimány study area. (1) Regression grouping; (2) Soil depth (cm); (3) Field code; (4) Soil parameter; (5) Standardized $\beta$ coefficient; (6) Significant correlation. Remark: *Basic soil investigations (upper limit of plasticity, humus content, $\mathrm{pH}$, lime content). ***Extended soil investigations (basic soil investigations and macronutrient (NPK) investigations). ***Completed soil investigations (basic soil investigations, extended soil investigations, micronutrient $\left(\mathrm{Mg}^{2+}, \mathrm{Na}^{+}, \mathrm{Zn}^{2+}\right.$, $\mathrm{Cu}^{2+}, \mathrm{Mn}^{2+}, \mathrm{SO}_{4}^{2-}, \mathrm{Fe}^{2+}+\mathrm{Fe}^{3+}$ ) investigations). $* * * *$ Average altitude (m).

Open Access nyilatkozat: A cikk a Creative Commons Attribution 4.0 International License (https://creativecommons.org/licenses/by/4.0) feltételei szerint publikált Open Access közlemény, melynek szellemében a cikk bármilyen médiumban szabadon felhasználható, megosztható és újraközölhető, feltéve, hogy az eredeti szerző és a közlés helye, illetve a CC License linkje és az esetlegesen végrehajtott módosítások feltüntetésre kerülnek. (SID_1) 